\title{
PERANAN BANK INDONESIA DALAM PELAKSANAAN PEMBERIAN DAN PENCABUTAN IZIN USAHA BANK
}

\author{
Oleh: \\ Elfrin Sagita Christ Dharny Manurung \\ Dewa Gde Rudy, SH., M.Hum \\ Hukum Perdata Fakultas Hukum Universitas Udayana
}

\begin{abstract}
ABSTRAK
Artikel ini membahas peran Bank Indonesia secara hukum terkait pelaksanaan pemberian dan pencabutan ijin usaha bank nasional yang bermasalah. Penelitian ini dilakukan dengan analisa hukum primer untuk membuktikan secara yuridis dan empiris peran serta fungsi Bank Indonesia sebagai bank sentral dalam pelaksanaan pemberian dan pencabutan ijin usaha bank nasional yang bermasalah. Data lapangan yang dikumpulkan dengan melakukan wawancara dengan responden dan informan secara langsung. Hasil penelitian menunjukan pertumbuhan bank nasional yang semakin cepat dan tidak terkendali dipengaruhi oleh aturan pemerintah tentang liberisasi perbankan nasional, yang tidak diimbangi dengan sistem perbankan nasional yang memadai. Hasil penelitian ini diharapkan dapat memberi dukungan kepada Bank Indonesia untuk melakukan fungsinya sebagai badan pemberi persetujuan atau penolakan perizinan, serta menggunakan haknya untuk melakukan penelitian, analisa dan penilaian setiap permohonan izin pendirian bank. Selain itu, Bank Indonesia juga mampu melakukan tindakan penyelamatan dan penyehatan kepada bank yang ditemukan terkait dengan permasalahan sebelum mencabut izin usaha bank yang akan dilikuidasi. Berdasarkan hasil penelitian disarankan kepada pemohon izin untuk melengkapi semua syarat yang tertera dalam perundang-undangan dan bersikap lebih koperatif dalam menyelesaikan masalah perbankannya.
\end{abstract}

Kata kunci : Peranan Bank Indonesia, izin usaha perbankan, likuidasi, pemberian pencabutan izin, izin BI

\begin{abstract}
As the central Bank, the Bank Indonesia has a role to stewardship and supervise the Indonesian banking. The aims of the research is to examine the legal aspect of the roles of Bank Indonesia in relation to granting and revocation of bank licenses for those bank in trouble. This research was conducted using an empirical juridical analysis of the primary legal materials which include field data and interview. Liberalization of the national banks by the government could led to the rise of the new system which potentially can cause problems for the bank in the future. Therefore, there is a need to strengthen the role of Bank Indonesia in the field of licensing. The result indicated that
\end{abstract}


from the legal aspect, Bank Indonesia has a right to grant approval or rejection, and to conduct research, analysis and assessment on the bank permit applications. Bank Indonesia also has right to rescue or restructure of the bank in trouble prior to liquidate bank licenses. Therefore, the bank license applicants need to fulfill all of the requirement as require by the legislation and need to be more cooperative to complete all requirement stated by legislation and also be more cooperative in the future if found problems in the bank so that the bank can return to normal.

Keywords: The role of Bank of Indonesia, bank operating license, liquidation, granting and repealing license, license from Bank of Indonesia

\section{Pendahuluan}

\subsection{Latarbelakang}

Untuk mencapai sasaran-sasaran pertumbuhan ekonomi, pendapatan perkapita, kesempatan kerja, distribusi pendapatan dan lain sebagainya, diperlukan sumber dana yang tidak kecil. Oleh karena itu, untuk mencapai sasaran-sasaran ini terus diupayakan meningkatkan kualitas pembangunan nasional dari waktu ke waktu, sehingga penting untuk memperbaiki dan memperkuat sector keuangan bidang industri perbankan.

Pada era globalisasi saat ini, bank sentral memegang peranan penting sebagai bagian dari sistem keuangan dan pembayaran suatu negara, maupun dunia. Kegiatan perbankan dapat berjalan oleh dana masyarakat atas dasar kepercayaan dan perlu pihak perbankan secara terus-menerus untuk menjaga kepercayaan tersebut. Sebagai bank sentral, Bank Indonesia memiliki peranan untuk menentukan dan mengarahkan perbankan nasional dalam melindungi masyarakat, untuk itu Bank Indonesia berwenang dan wajib membina serta mengawasi seluruh kegiatan perbankan. ${ }^{1}$

Alasan mengapa sistem perbankan nasional merosot saat ini disebabkan perilaku beberapa pengelola dan pemilik bank yang selalu memanfaatkan dan / atau lalai dengan prinsip kehatihatian dalam berusaha, selain lemahnya pengawasan Bank Indonesia.

Penting dan strategisnya peranan bank sentral untuk menciptakan sistem perbankan nasional yang sehat dan efisien dapat diwujudkannya dengan pertimbangan bahwa dunia perbankan merupakan pilar utama pembangunan

\footnotetext{
${ }^{1}$ Muhammad Djumhana, 2000, Hukum Perbankan Indonesia, Cetakan III, PT Citra Aditya Bakti, Bandung, h.276
} 
ekonomi suatu negara. Fungsi khusus bank sentral juga penting dalam mencegah terjadinya risiko-risiko kerugian baik yang dialami oleh perbankan itu sendiri, maupun masyarakat yang menyimpan dana, serta secara global dapat merugikan dan membahayakan perekonomian negara tersbut. Untuk itu Bank Indonesia bertanggungjawab dan perlu mewujudkan sistem perbankan yang sehat dan berkesinambungan. Adapun tujuan penelitian ini adalah untuk menggambarkan kewenangan Bank Indonesia untuk memberikan dan mencabut izin usaha perbankan nasional serta menjelaskan akibat yang diterima bank yang melanggar aturan perbankan nasional dalam hal usaha bank.

\subsection{Rumusan Masalah}

1. Bagaimana peranan Bank Indonesia dalam melaksanakan pemberian izin usaha bank umum?

2. Bagaimana peranan Bank Indonesia dalam mencabut izin usaha bank umum yang bermasalah dan melikuidasi?

\subsection{Tujuan Penulisan}

Tujuan penulisan penelitian ini adalah memberikan pengetahuan dan penjelasan bagaimana Bank Indonesia memiliki wewenang memberikan dan mencabut izin usaha perbankan nasional serta menjelaskan tentang akibat yang diterima bank yang melakukan pelanggaran aturan perbankan dalam hal usaha bank.

\section{Isi Makalah}

\subsection{Metode Penelitian}

Penelitian ini adalah penelitian hukum yuridis empiris untuk mengkaji dan mencari pemecahan terhadap masalah yang dikemukakan. Yang dimaksud dengan penelitian hukum yuridis empiris adalah penelitian lapangan untuk memperoleh data sebagai data primer. $^{2}$ Dalam hal ini dikaji suatu permasalahan hukum dengan melakukan analisa terhadap bahan hukum primer yang meliputi data lapangan. Data lapangan adalah data yang dikumpulkan secara langsung dari responden dan informan sebagai sumber pertama di lapangan.

2 Abdulkadir Muhammad, 2004, Hukum Dan Penelitian Hukum, PT. Citra Aditya Bakti, Bandung, h.101. 


\subsection{Hasil dan Pembahasan}

\subsubsection{Peranan Bank Indonesia Dalam Pemberian Izin Usaha Bank Umum}

Ketentuan utama yang mengatur operasional kelembagaan suatu bank terdapat pada UU No. 7 Tahun 1992, tentang Perbankandan telah diubah dengan UU No. 10 Tahun 1998, serta UU No. 23 Tahun 1999 tentang Bank Indonesia dan diubah dengan UU No. 3 Tahun 2004. Menurut UU No. 10 Tahun 1998, pasal 29 ayat (1) ditentukan bahwa "Pembinaan dan pengawasan bank dilakukan oleh Bank Indonesia”. Kebijakan pengaturan dan pengawasan bank yang dirumuskan dan diimplementasikan oleh Bank Indonesia, selaku otoritas perbankan nasional, bertujuan untuk meniptakan individual bank dan sistem perbankan yang sehat. ${ }^{3}$

Berdasarkan penelitian yang telah dilakukan, pemberian izin mendirikan dan melakukan kegiatan usaha bank dilakukan menurut ketentuan Peraturan Bank Indonesia No.11/1/PBI/2009 tentang Bank Umum, pada Pasal 4.

Sesuai ketentuan Pasal 6 pada peraturan tersebut, "bank hanya dapat didirikan dan/atau dimiliki oleh: a. warga Negara Indonesia dan/atau badan hukum Indonesia; atau b. warga negara Indonesia dan/atau badan hukum Indonesia dengan warga negara asing dan/atau badan hukum asing secara kemitraan".

Dalam mendirikan bank diperlukan adanya modal, menurut pasal 5 pada peraturan tersebut "modal disetor untuk mendirikan bank ditetapkan paling kurang sebesar Rp 3.000.000.000.000,00 (tiga triliun rupiah)".

Untuk perizinan dan mendirikan Bank Umum dilakukan melalui 2 tahap. Tahap pertama, pengajuan izin usaha bank, calon pemilik mengirimkan surat permohonan persetujuan prinsip kepada Bank Indonesia. Dalam surat permohonan perlumemperlihatkan kesungguhan dan persiapan pendirian bank serta melengkapi rencana operasional bank. Jika permohonan tersebut disetujui oleh Bank Indonesia, calon pemilik bank selanjutnya mengajukan surat permohonan izin usaha kepada Bank Indonesia dan menyertakan kesiapan akhir dalam pendirian bank. Jika dalam jangka waktu setahun, pemohon belum

\footnotetext{
${ }^{3}$ Sylvia Janissriwati, 2011, Aspek Hukum Kewenangan Bank Indonesia dalam Kepailitan Suatu Bank, LoGoz Publishing, Bandung, h.82.
} 
mengajukan surat permohonan izin usaha kepada Bank Indonesia, maka surat persetujuan prinsip tersebut tidak berlaku lagi.

Dalam prosesnya, pihak pemohon wajib melakukan presentasi di hadapan Bank Indonesia untuk menerangkan rencana operasional pendirian bank yang dimaksud. Disetujui tidaknya surat permohonan izin usaha bank diproses selama 60 hari kerja setelah seluruh dokumen diterima lengkap. Ketentuan dan prosedur pengajuan persetujuan prinsip dan izin usaha ini serta kelengkapan dokumennya diatur dalam Peraturan Bank Indonesia No. 11/1/PBI/2009.

\subsubsection{Wewenang Bank Indonesia Dalam Pencabutan Izin Usaha Bank Dalam Konteks Likuidasi}

Setiap bank diwajibkan mengirimkan laporan keuangan yang berisi neraca dan perhitungan laba rugi beserta penjelasannya sesuai format yang telah ditetapkan oleh Bank Indonesia. Dari laporan keuangan tersebut, Bank Indonesia melakukan analisis likuiditas dan solvabilitas bank bersangkutan. Jika dianggap membahayakan, Bank Indonesia dapat mengambil tindakan pengamanan sesuai ketetapan dan prosedur yang berlaku.

Menurut Surat Keputusan Direksi Bank Indonesia No. 32/53/KEP/DIR tentang Tata Cara Pencabutan Izin Usaha, Pembubaran dan Likuidasi Bank Umum, disebutkan pada Pasal 2: "pencabutan izin usaha bank dilakukan oleh Direksi Bank Indonesia apabila tindakan penyelamatan sebagaimana dimaksud dalam Pasal 37 ayat (1) UU No. 10 Tahun 1998 tentang Perbankan belum cukup mengatasi kesulitan yang dihadapi bank, atau menurut penilaian Bank Indonesia keadaan suatu bank dapat membahayakan sistem perbankan, atau terdapat permintaan dari pemilik atau pemegang saham".

Dicabutnya izin usaha bank olehBank Indonesia dapat disebabkan karena bank tersebut tidak mampu keluar dari permasalahan dan kesulitannya atau jika keadaan bank bersangkutan telah membahayakan sistem perbankan nasional. Sebelum dilakukan pencabutan izin usaha bank, pihak Bank Indonesia terlebih dahulu melaksanakan langkah-langkah permulaan sehingga pencabutan izin tersebut adalah langkah akhir tindkan penyehatan bank.

Proses pencabutan izin usaha bank karena permintaan pemegang saham bank dapat dilakukan dalam 2 tahap, yaitu: 1) permohonan persetujuan pencabutan izin usaha bank; dan 2) keputusan pencabutan izin usaha bank. 
Tindakan selanjutnya jika pencabutan izin usaha bank disetujui, bank tersebut wajib melakukan pembubaran badan hukum dengan ketentuan undang-undang yang berlaku, dan mengumumkan secara luas kepada masyarakat secara luas. Apabila bank yang telah dicabut izin usahanya memiliki kantor di luar negeri, Bank Indonesia dengan segera memberitahukan kepada otoritas yang berwenang di negara tersebut.

Kewenangan mencabut izin usaha bank merupakan kewenangan Bank Indonesia sebagai kewenangan diskresioner. Kewenangan diskresioner adalah kewenangan mencabut izin usaha suatu bank karena telah gagal memenuhi standar prudential yang ditetapkan. Likuidasi bank adalah teknis atau cara serta proses penyelesaian hak dan kewajiban bank, yang merupakan proses keperdataan untuk mengakhiri atau membubarkan badan hukum dan menyelesaikan hak dan kewajiban bank. Termasuk di dalam likuidasi yaitu menjual aset, menagih piutang dan membayar utang bank serta melindungi hak nasabah bank. Selama proses likuidasi, Bank Indonesia melakukan pengawasan terhadap tim likuidasi dengan tujuan untuk menilai pelaksanaan tugas dan wewenang tim likuidasi serta memberhentikan dan mengganti anggota tim likuidasi.

\section{Penutup}

\subsection{Kesimpulan}

Peranan Bank Indonesia sebagai pemberi izin prinsip dan usaha bank umum dilaksanakan dalam 2 tahap yaitu: 1) mengawasi dan memutuskan diberikan atau tidaknya izin prinsip pendirian usaha bank umum; 2) mengawasi dan memberikan izin usaha bank setelah pemohon dinyatakan siap untuk mendirikan bank tersebut.

Peranan Bank Indonesia dalam kewenangannya mencabut izin usaha bank yang bermasalah atau melakukan tindakan likuidasi adalah mengupayakan tindakan penyelamatan atau penyehatan bank bersangkutan sesuai tahapan dan ketentuan yang berlaku. Adapun tahapan tersebut termasuk didalamnya adalah penilaian kondisi bank, merger, konsolidasi, akuisisi, likuidasi dan kepailitan. Apabila upaya penyelamtan dan penyehatan tersebut tidak berhasil maka Bank Indonesia akan melikuidasi bank tersebut dengan cara membentuk tim likuidasi. 


\subsection{Saran}

Untuk mempermudah mendapatkan izin usaha bank dari Bank Indonesia, sebaiknya pemohon terlebih dahulu melengkapi semua persyaratan yang tertera dalam perundang-undangan, agar saat menjalani proses pengajuan permohonan tidak mengalami hambatan.

Hendaknya bank yang bermasalah lebih koperatif dalam menjalani tindakan-tindakan penyelamatan atau penyehatan yang dilakukan Bank Indonesia.

\section{DAFTAR PUSTAKA}

\section{Daftar Buku}

Muhammad, Djumhana, 2000, Hukum Perbankan Indonesia, Cetakan III, PT Citra Aditya Bakti, Bandung

Usman, R. (2001). Aspek-aspek hukum perbankan di Indonesia: Gramedia Pustaka Utama.

Muhammad, Abdulkadir, 2004, Hukum Dan Penelitian Hukum, PT. Citra Aditya Bakti, Bandung

Muhammad, D. (2006). Hukum Perbankan di Indonesia. Citra Aditya Bakti, Bandung.

Sylvia, Janissriwati, 2011, Aspek Hukum Kewenangan Bank Indonesia dalam Kepailitan Suatu Bank, LoGoz Publishing, Bandung

Imaniyati, N. S., \& Putra, P. A. A. (2016). Pengantar Hukum Perbankan Indonesia: Refika Aditama.

\section{Daftar Jurnal}

Yatna, K. G. S. S., \& Mudana, N. (2016). Peranan Lembaga Penjamin Simpanan Dalam Kaitannya Dengan Likuidasi BPR (Study Pada Pengawas Bank Madya di Bank Indonesia Cabang Denpasar). Kertha Semaya : Journal Ilmu Hukum, 04(03), URL https://ojs.unud.ac.id/index.php/kerthasemaya/article/view/19803

Sari Wiradiani, N. W., \& Ariawan, I. G. K. (2013). Tanggung Jawab Dan Kewenangan Bank Indonesia Dalam Likuidasi Bank. Kertha Semaya : Journal Ilmu Hukum, 01(07), URL https://ojs.unud.ac.id/index.php/kerthasemaya/article/view/6353

Baskara, I. G. K. (2014). Lembaga Keuangan Mikro Di Indonesia. Buletin Studi Ekonomi, 18(2), URL https://ojs.unud.ac.id/index.php/bse/article/view/7788 


\section{Perundang-undangan}

Undang-Undang Nomor 10 Tahun 1998 Tentang Perubahan Atas Undang Undang Nomor 7 Tahun 1992 Tentang Perbankan.

Undang-Undang Nomor 3 Tahun 2004 Tentang Perubahan Atas Undang Undang Nomor 23 Tahun 1999 Tentang Bank Indonesia.

Surat Keputusan Direksi Bank Indonesia No. 32/53/KEP/DIR Tentang Tata Cara Pencabutan Iziin Usaha, Pembubaran, dan Likuidasi Bank Umum 